\title{
Perancangan Sistem Informasi Perpustakaan Berbasis Web Dengan Pemanfaatan Barcode Scanner di MI Nurul Huda Argopeni
}

\author{
Slamet $^{1}$, Mukhamad ${ }^{2}$ \\ 1,2 Program Studi Teknik Informatika, Universitas Ma'arif Nahdlatul Ulama Kebumen \\ ${ }^{1}$ parkmetjr@gmail.com*, ${ }^{2}$ hasimumnukebumen@gmail.com
}

\begin{abstract}
Based on observations made, library processing at MI Nurul Huda Argopeni is currently still manual and does not have an information system, causing new problems such as prone to recording errors, data inaccuracies. Manual records can be lost, damaged, torn, mixed or piled up with other documents and the service becomes slow and ineffective. Therefore, a library information system is needed with the use of barcode scanner technology that can facilitate librarianship officers in managing book circulation quickly, precisely, automatically and improving services to students that are better, accurate, effective, and efficient in the use of time, place, and energy. .

The purpose of this research is to design a web-based library information system for MI Nurul Huda Argopeni that supports barcode scanners. In designing this application the author uses the stages of SDLC development with the Waterfall process model and system design using the UML (Unified Modeling Language) model. The design of this library information system can facilitate the librarian in managing books and improving the quality of service to students at the MI Nurul Huda Argopeni library.
\end{abstract}

The programming language that the author uses is PHP and uses a MySQL database. To test the feasibility of the system, the author uses black box testing. The final result of this research is the creation of a web-based library information system application at MI Nurul Huda Argopeni that supports barcode scanners.

Keywords: Library Information System, PHP, MySQL

\begin{abstract}
Abstrak
Berdasarkan observasi yang dilakukan, pengolahan perpustakaan di MI Nurul Huda Argopeni saat ini masih bersifat manual belum memiliki sistem informasi, sehingga menimbulkan masalah baru seperti cenderung rawan terjadi kesalahan pencatatan, adanya ketidakakuratan data. Catatan manual bisa saja hilang, rusak, sobek, tercampur atau tertumpuk dengan dokumen yang lain dan pelayanan menjadi lambat dan tidak efektif. Oleh karena itu, diperlukan sistem informasi perpustakaaan dengan pemanfaatan teknologi barcode scanner yang dapat mempermudah petugas perpustakaaan dalam pengelolaan sirkulasi buku secara cepat, tepat, otomatis dan meningkatkan pelayanan kepada siswa yang lebih baik, akurat, efektif, dan efisiensinya penggunaan waktu, tempat, maupun tenaga.

Tujuan dari penelitian ini adalah merancang sistem informasi perpustakaan berbasis web MI Nurul Huda Argopeni yang support barcode scanner. Dalam perancangan aplikasi ini penulis menggunakan tahapan-tahapan dari pengembangan SDLC dengan model proses Waterfall dan perancangan sistem menggunakan model UML (Unified Modeling Language). Perancangan sistem informasi perpustakaan ini dapat mempermudah petugas perpustakaaan dalam pengelolaan buku dan meningkatkan kualitas pelayanan kepada siswa di perpustakaan MI Nurul Huda Argopeni. Bahasa pemrograman yang penulis gunakan adalah PHP dan menggunakan database MySQL. Untuk menguji kelayakan sistem, penulis menggunakan blak bock testing. Hasil akhir dari penelitian ini adalah pembuatan aplikasi sistem informasi perpustakaan berbasis web di MI Nurul Huda Argopeni yang support barcode scanner.
\end{abstract}

Kata kunci: Sistem Informasi Perpustakaan, PHP, MySQL

\section{Pendahuluan}

Peranan teknologi informasi setelah menyebar hampir disemua bidang, tidak terkecuali di bidang perpustakaan. Perpustakaan adalah institusi yang menyediakan koleksi bahan perpustakaan tertulis, tercetak dan terekam sebagai pusat sumber informasi yang diatur menurut sistem dan aturan yang baku dan untuk keperluan pendidikan, penelitian dan intelektual bagi siswa/siswi.

Sesuai dengan misinya yaitu untuk mencerdaskan dan membuat siswa gemar membaca buku, tentunya sekolah MI Nurul Huda Argopeni memiliki perpustakaan sebagai sarana penunjang 
untuk mencapai tujuan tersebut. Namun, dalam pengelolaannya masih bersifat manual belum menggunakan sistem informasi karena terbatasnya fasilitas sarana dan prasarana yang berbasis komputer. Sampai saat ini pengeloaan input data inventaris buku, absensi pengunjung, data anggota, transaksi peminjaman dan pengembalian buku diolah menggunakan catatan di buku besar perpustakaan dan kartu bukti peminjam. Penulisan data menggunakan catatan cenderung terdapat kesalahan pencatatan dan adanya ketidakakuratan data. Selain itu, kekurangannya adalah dalam penyimpanan data. Data yang tersimpan dalam bentuk buku bisa saja hilang, rusak, sobek, tercampur atau tertumpuk dengan dokumen yang lain.

Perpustakaan MI Nurul Huda Argopeni saat ini belum memiliki petugas tetap sehingga pelayanan transaksi dilakukan oleh seorang guru yang sekaligus bertindak sebagai petugas perpustakaan. Kondisi ini memungkinkan pencatatan transaksi peminjaman dan pengembalian buku menjadi lambat dan kurang efektif mengingat jam istirahat siswa yang cukup singkat. Petugas perpustakaan kesulitan dalam mendapatkan informasi penting terkait bukubuku yang paling diminati peminjam karena kesibukan di kelas dan perpustakaan sehingga laporan data peminjaman atau pengembalian yang tertulis di catatan manual tidak terkontrol dengan baik.

Faktor kendala inilah yang mendukung pentingnya penggunaan komputer dalam mengolah data di perpustakaan dan diperlukannya sebuah sistem informasi perpustakaan untuk menunjang kinerja pada perpustakaan itu sendiri yang berbasis komputerisasi. Selain itu dibutuhkan pula perangkat keras pendukung untuk mengembangkaan sistem informasi perpustakaaan dengan pemanfaatan teknologi barcode scanner. Dengan kombinasikan teknologi ini, diharapkan mempermudah petugas perpustakaan dalam pemberian layanan kepada siswa, misalnya scanning ID buku, scanning ID anggota, sehingga kendala-kendala dalam memberikan layanan kepada siswa dapat diminimalkan. Sistem informasi layanan perpustakaan berbasis teknologi barcode scanner dipilih menjadi alternatif pemberian layanan dikarenakan mudah, cepat, tepat, otomatis dan meningkatkan pelayanan yang lebih baik, akurat, efektif, dan efisiensinya penggunaan waktu, tempat, maupun tenaga di perpustakaan MI Nurul Huda Argopeni.

Berdasarkan latar belakang diatas, maka perlu suatu langkah untuk mempermudah pengelolaan perpustakaan pada MI Nurul Huda Argopeni tersebut. Rumusan masalah yang akan diuraikan pada penelitian ini yaitu bagaimanakah membuat perancangan Sistem Informasi Perpustakaan
Berbasis Web dengan pemanfaatan Barcode Scanner di MI Nurul Huda Argopeni.

Tujuan dari penelitian ini adalah membuat Perancangan Sistem Informasi Perpustakaan Berbasis Web dengan Pemanfaatan Barcode Scanner pada MI Nurul Huda Argopeni Banjarmasin. Adapun Manfaat yang diharapkan yaitu memberi alternatif solusi dan peningkatan dalam pelaksanaan kinerja sistem keperpustakaan serta untuk meningkatkan efisiensi dan produktivitas sistem keperpustakaan maupun infrastruktur yang ada di MI Nurul Huda Argopeni.

\section{Metode Penelitian}

\subsection{Alat Dan Bahan}

Alat-alat yang digunakan oleh peneliti dalam melaksanakan penelitian ini diantaranya perangkat keras (Hardware) dan perangkat lunak (Software) seperti ditunjukkan dalam tabel 2.1 berikut:

Tabel 1. Perangkat Keras dan Lunak

\begin{tabular}{ccc}
\hline No. & Komponen & LoG \\
\hline 1. & Prosessor & Intel Pentium (R) CPU \\
& P6100@2.00GHz \\
2. & Harddisk & $500 \mathrm{~Gb}$ \\
3. & RAM & $3 \mathrm{~Gb}$ \\
4. & Monitor & LED 14" \\
5. & Keyboard & Standard Keyboard \\
6. & Mouse & Standard Mouse \\
7. & Barcode & USB Barcode Scanner 2D QR 1D \\
& Scanner & Windows 8 Pro \\
8. & Operating & XAMPP version 3.2.2, Apache, \\
& sistem & MySql, PHPmyadmin \\
9. & XAMPP & Google Chrome \\
10. & Browser & Balsamiq Wirefraame 4.1.10 \\
11. & Desain UI & Notepad ++ 7.8.8 \\
12. & Text Editor & Visio 2013 \\
13. & Ms Office &
\end{tabular}

Bahan penelitian yang digunakan antara lain buku absensi pengunjung, data anggota, buku inventaris perpustakaan, dan kartu bukti peminjam.

\subsection{Metode Pengumpulan Data}

Untuk mendapatkan data yang benar-benar akurat, relevan, valid dan realiable maka peneliti menggunakan beberapa metode dalam melakukan pengumpulan data. Pengumpulan data dilakukan dengan metode:

a. Wawancara

Dalam riset penulis melakukan tatap muka dan tanya jawab langsung dengan sumber data atau pihak-pihak yang berkepentingan untuk memperoleh data-data yang ada kaitannya dengan permasalahan yang akan dibahas yaitu mengenai perpustakaan.

b. Observasi

Observasi dilakukan untuk mengamati dan pencatatan terhadap gejala/peristiwa secara 
langsung yang sedang berjalan. Metode ini digunakan untuk membantu proses analisis kebutuhan yang sesuai dengan tujuan penelitian ini.

c. Studi Kepustakaan

Penulis melakukan penelitian kepustakaan untuk memperoleh aspek- aspek teoritis dalam pengumpulan data dan informasi dengan membaca buku arsip sekolah, buku kegiatan sekolah, buku perkuliahan, jurnal internet dan literatur-literatur lainnya yang berhubungan dengan penulisan penelitian ini.

\subsection{Metode Pengembangan Sistem}

Metode pengembangan sistem yang digunakan dalam pernagkat lunak ini menggunakan metode System Development Live Cycle (SDLC) waterfall atau disebut siklus/tahapan hidup pengembangan sistem dengan tahapan sebagai berikut:

a. Analisis

Pada tahap ini dilakukan pengumpulan data dengan cara wawancara, observasi dan kajian pustaka untuk memperoleh gambaran sistem dengan menganalisis proses yang berjalan, kebutuhan user, data perpustakaan, fitur/konten yang nantinya digunakan sebagai acuan untuk desain sistem yang diusulkan di perpustakaan MI Nurul Huda Argopeni.

b. Desain

Pada tahap ini dilakukan perancangan terhadap perangkat lunak yang akan dibangun. Perancangan-perancangan dalam sistem ini meliputi perancangan sistem berorientasi objek dengan model dalam bentuk Unified Modeling Language (UML) yang terdiri dari use case diagram, class diagram, activity diagram, dan sequence diagram. Selain itu juga ada perancangan interface sistem yang terdiri dari perancangan prototype menggunakan balsamiq wireframe dan basis data.

c. Pembuatan Kode Program

Pada tahap ini dilakukan pengkodean yang merupakan translasi dari tahap desain. Tahap pengkodean penulis menggunakan bahasa pemrograman PHP (Hypertext Preprocessor) menggunakan perangkat lunak Notepad ++ .

d. Pengujian

Tahap ini dilakukan pengujian program yang sudah dibuat. Pengujian dilakukan dengan pengujian blackbox testing, hal ini dilakukan untuk untuk menguji kelancaran fungsional program dan untuk melihat apakah sistem yang telah dibuat sudah sesuai dengan tujuan awal pembuatan dan layak untuk dipergunakan.

e. Pendukung atau Pemeliharaan

Tahap pendukung atau pemeliharaan diimplementasikan dengan melakukan update terhadap konten serta menyesuaikan dengan informasi yang berubah atau bertambah.

\section{Hasil dan Pembahasan}

3.1. Analisis

a. Sistem yang berjalan

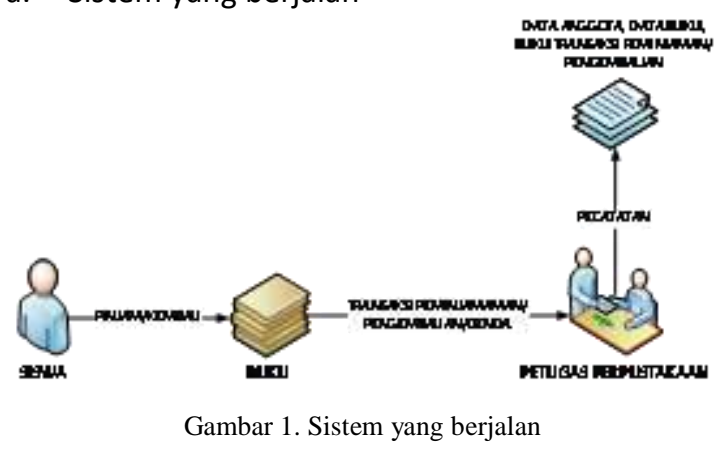

Pada gambar 1. Menunjukan bahwa pengelolaan di perpustakaan MI Nurul Huda Argopeni masih menggunakan cara manual.

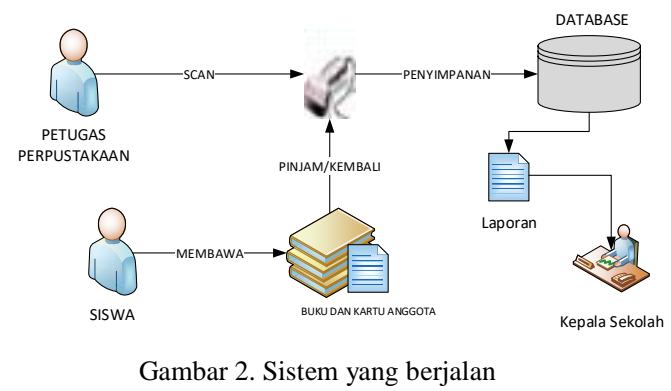

Pada gambar 2. menunjukan bahwa sistem baru yang diusulkan dengan komputerisasi dan memanfaatkan teknologi barcode scanner. Barcode digunakan untuk mempercepat proses pencatatan kegiatan peminjaman dan pengembalian koleksi. Alat ini juga meminimalisir kesalahan penulisan kode koleksi, baik buku ataupun media. Proses sistem yang diusulkan di perpustakaan MI Nurul Huda Argopeni.

\subsection{Perancangan}

Kegiatan-kegiatan yang dilakukan dalam perancangan sistem ini antara lain:

a. Perancangan Use Case

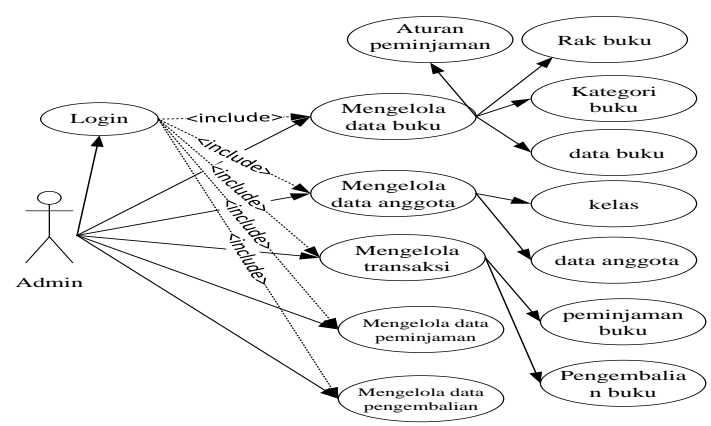


Gambar 3. Sistem yang berjalan

Gambar 3 menunjukan Use Case Diagram menggambarkan interaksi antara aktor dengan proses atau sistem yang dibuat. Use case pada sistem yang dibangun ini terdiri dari 1 (satu) aktor tunggal yaitu admin. Admin yaitu aktor dapat melakukan login, mengelola akun lever user, kelola dashboard administrator, data buku, data anggota, data transakasi, data peminjaman dan data peminjaman.

b. Perancangan Basis Data

Database berfungsi sebagai tempat penyimpanan data-data penting yang nantinya bakal diolah lagi untuk keperluan di waktu yang akan datang. Dalam perancangan database ini terdiri dari tabel user, siswa, kelas, rak buku, kategori, buku, peminjaman, transaksi, dan kompensasi

\section{c. Perancangan Antar Muka}

Perancangan antar muka bertujuan sebagai acuan untuk tahap implementasi dan juga memberi gambaran sistem yang akan dibangun. Perancangan tersebut antara lain graphic user interface untuk administrasi database, struktur menu dan tampilan system. Dalam perancangan antarmuka ini menggunakan software Balsamiq Wireframe.

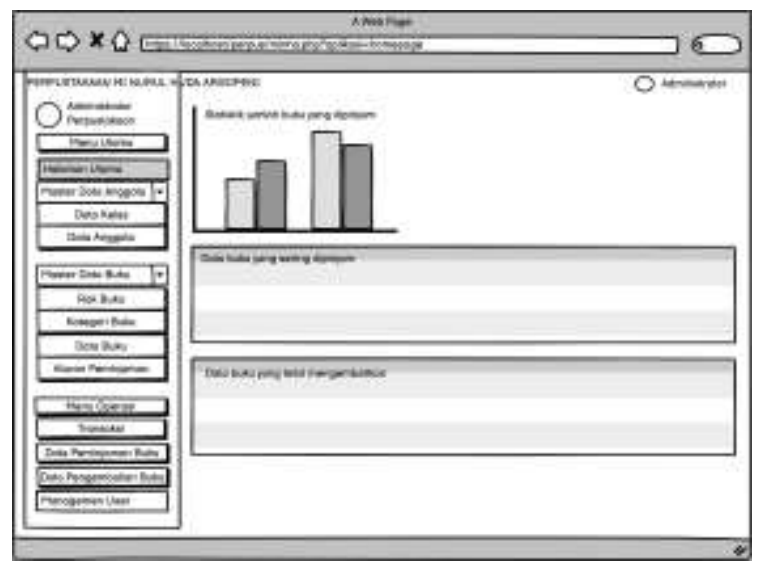

Gambar 4. Sistem yang berjalan

Gambar 4. menampilkan Halaman utama administrator digunakan untuk mengelola menu utama yang terdiri dari master data anggota, master data buku dan menu operasi yang terdiri dari menu tansaksi, data peminjaman buku, data pengembalian buku, dan managemen user.

\subsection{Perancangan}

a. Basis Data

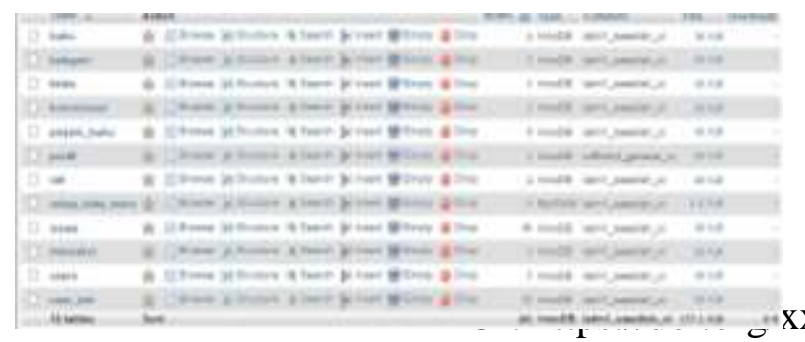

Gambar 5. Sistem yang berjalan

Gamabr 5. merupakan implementasi basis data sistem informasi pengolahan data perpustakaan dengan total 12 tabel yang mana setiap data yang menjadi record dari setiap proses pengelolaan akan ditampung ke dalam database yang dibuat.

b. Website

1) Tampilan Halaman Login Admin

Halaman ketika saat pertama membuka sistem informasi perpustakaan.

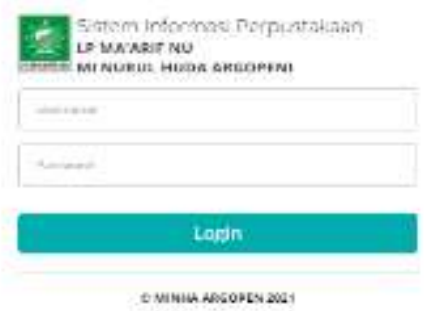

Gambar 6. Halaman Login

2) Tampilan Halaman Administrator

Halaman ketika admin telah berhasil login dan langsung di bawa ke halaman beranda admin.

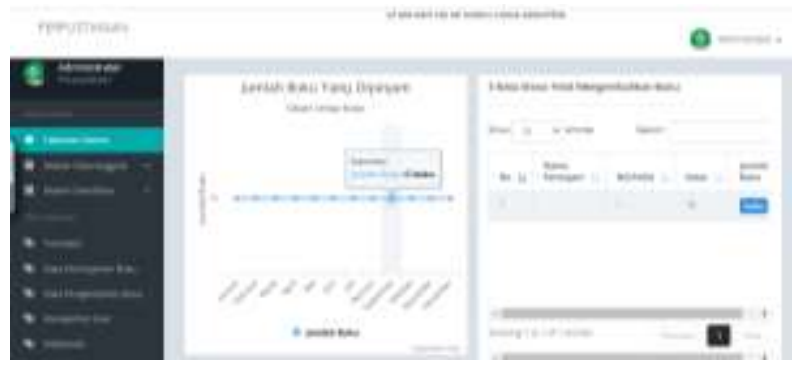

Gambar 7. Halaman Administrator

3) Tampilan Halaman Data Anggota

Halaman form data anggota setelah admin menambahkan anggota yang terdaftar di perpustakaan.

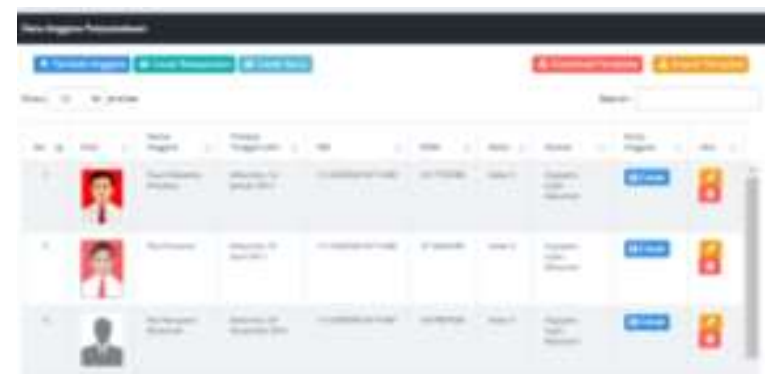

Gambar 8. Halaman data anggota 
Halaman form laporan data peminjaman buku.

4) Tampilan Halaman Data Buku

Halaman form data buku yang telah berhasil ditambahkan.

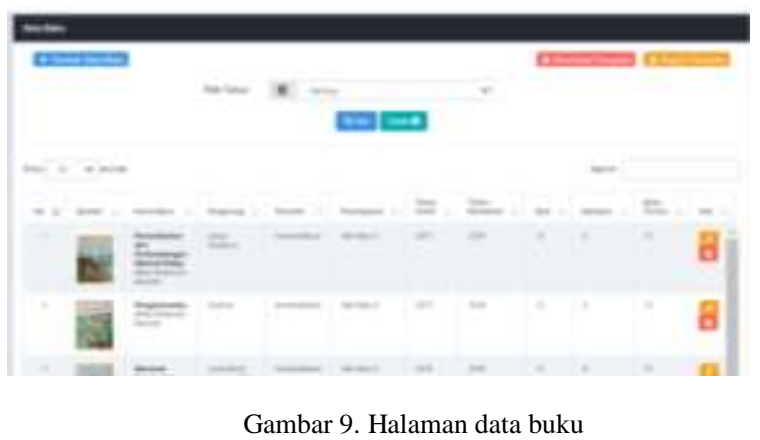

5) Tampilan Halaman Transaksi Peminjaman Halaman form transaksi peminjaman buku ketika ada siswa yang meminjam buku.

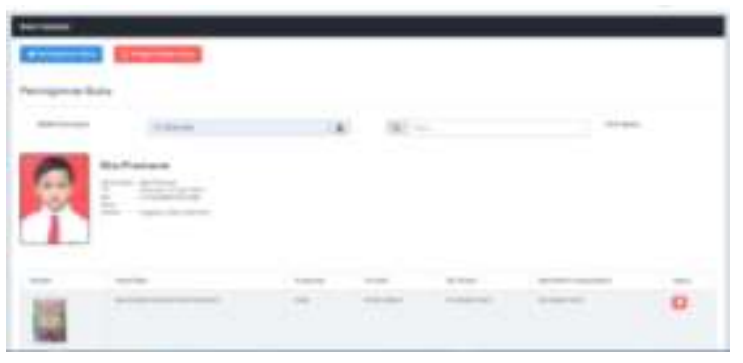

Gambar 10. Halaman transaksi peminjaman

6) Tampilan Transaksi Pengambilan Halaman form transaksi pengembalian buku.

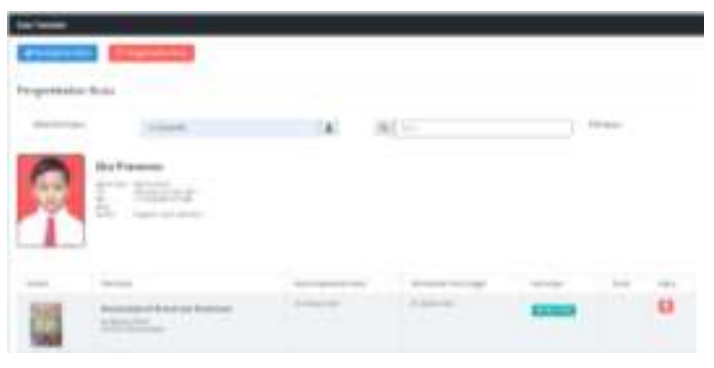

Gambar 11. Halaman transaksi penghambilan buku

7) Tampilan Laporan Data Peminjaman Halaman form laporan data peminjaman buku.

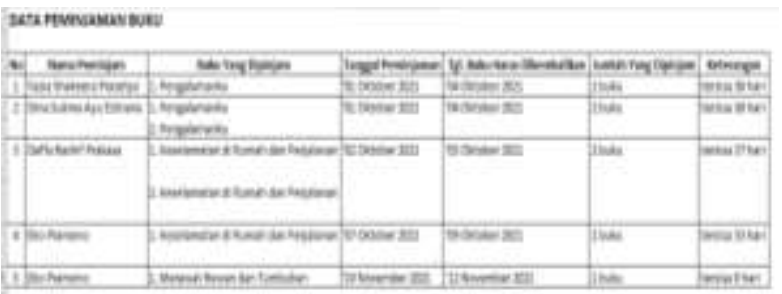

Gambar 12. Halaman laporan peminjaman buku

8) Tampilan Laporan Data Pengambilan

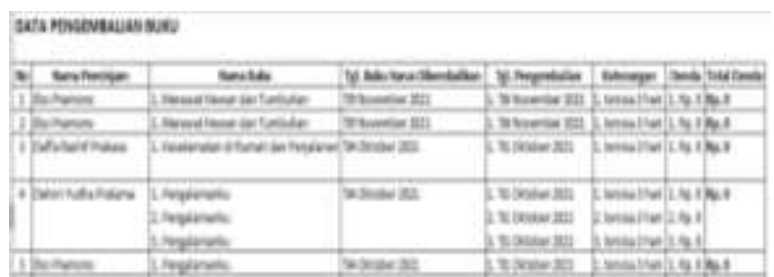

Gambar 13. Halaman laporan pengambilan

\subsection{Pengujian}

Pengujian berfungsi untuk mengetahui apakah sistem yang dibangun sudah sesuai dengan target yang diharapkan. Pada pengujian penelitian ini penulis menggunakan black box testing. Metode ini mencari kesalahan pada fungsi yang salah atau hilang, kesalahan pada interface, dan kesalahan pada struktur data atau akses database tanpa mengetahui struktur internal kode ataua program. Hal ini bertujuan untuk mengurangi masalah terhadap nilai masukan, pengujian terhadap fungsionalitas atau kegunaan sebuah aplikasi. Pada pembangunan sistem ini, dilakukan dua pengujian yaitu pengujian pada admin dan pengujian pada user/pengguna.

a. Pengujian Fungsi oleh Admin

\begin{tabular}{|c|c|c|c|c|}
\hline No. & $\begin{array}{c}\text { Fungsi } \\
\text { yang Diuji }\end{array}$ & Skenario & $\begin{array}{l}\text { Hasil yang } \\
\text { Diharapkan }\end{array}$ & Ket. \\
\hline 1. & $\begin{array}{c}\text { Fungsi } \\
\text { login }\end{array}$ & $\begin{array}{c}\text { Admin } \\
\text { memasukka } \\
\text { n username } \\
\text { dan } \\
\text { password } \\
\text { benar }\end{array}$ & $\begin{array}{l}\text { Admin masuk } \\
\text { ke halaman } \\
\text { sistem, sistem } \\
\text { menampilkan } \\
\text { dashboard }\end{array}$ & Berhasil \\
\hline 2. & $\begin{array}{c}\text { Fungsi } \\
\text { login }\end{array}$ & $\begin{array}{c}\text { Admin } \\
\text { memasukka } \\
\mathrm{n} \text { username } \\
\text { dan } \\
\text { password } \\
\text { salah }\end{array}$ & $\begin{array}{l}\text { Admin tidak } \\
\text { dapat masuk ke } \\
\text { halaman } \\
\text { dashboard dan } \\
\text { tetap pada } \\
\text { halaman login }\end{array}$ & Berhasil \\
\hline 3. & $\begin{array}{l}\text { Fungsi data } \\
\text { tambah } \\
\text { kelas }\end{array}$ & $\begin{array}{l}\text { Masuk ke } \\
\text { halaman } \\
\text { data kelas } \\
\text { kemudian } \\
\text { pilih button } \\
\text { tambah } \\
\text { kelas }\end{array}$ & $\begin{array}{l}\text { Tampil } \\
\text { form input } \\
\text { tambah data } \\
\text { kelas dan } \\
\text { melakukan } \\
\text { proses tambah } \\
\text { kelas kemudian } \\
\text { proses } \\
\text { penyimpanan } \\
\text { data serta } \\
\text { menampilkan } \\
\text { data kelas }\end{array}$ & Berhasil \\
\hline 4. & $\begin{array}{l}\text { Fungsi edit } \\
\text { data kelas }\end{array}$ & $\begin{array}{l}\text { Masuk ke } \\
\text { halaman } \\
\text { data kelas } \\
\text { kemudian } \\
\text { pilih } \\
\text { button edit } \\
\text { untuk data } \\
\text { kelas yang }\end{array}$ & $\begin{array}{c}\text { Melakukan } \\
\text { proses edit data } \\
\text { dan kemudian } \\
\text { pilih } \text { update } \\
\text { data jika ingin } \\
\text { diupdate jika } \\
\text { tidak maka pilih } \\
\text { batal. }\end{array}$ & Berhasil \\
\hline
\end{tabular}


6 Jurnal Riset Teknologi Informasi dan Komputer (JURISTIK), Vol. 1, No. 1, Juni 2021, hlm. 1-7

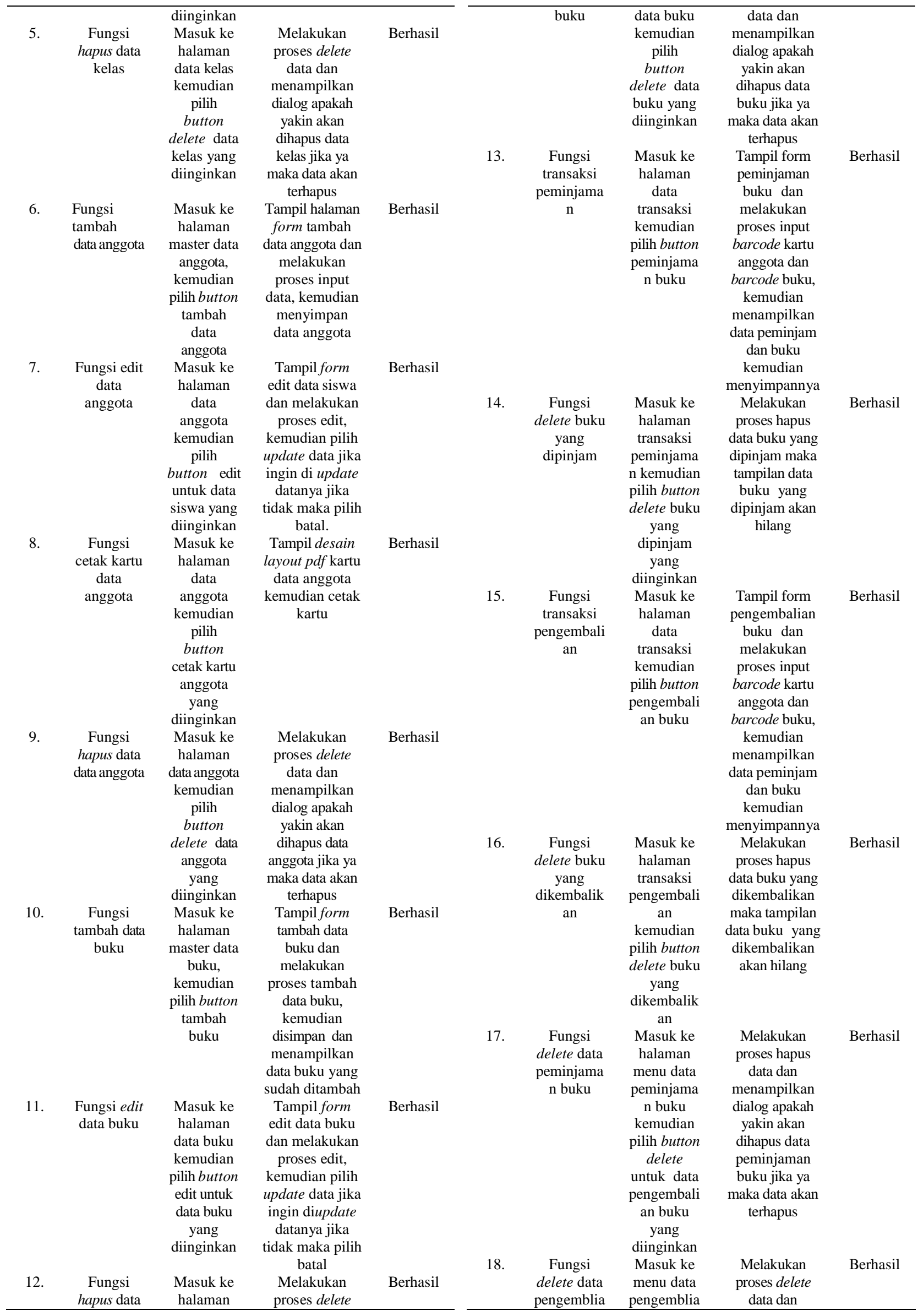




\begin{tabular}{cccc}
\hline n buku & n buku & menampilkan & \\
& kemudian & dialog apakah & \\
pilih button & yakin akan & & \\
delete data & dihapus data & \\
pengemblia & pengemblian & \\
& n buku & buku jika ya & \\
& yang & maka data akan & \\
& diinginkan & terhapus & \\
& Masuk ke & Melakukan klik & Berhasil \\
& halaman & menu & \\
Fungsi & administrat & administrator & \\
logout & or & kemudian pilih & \\
& & logout & \\
& & &
\end{tabular}

\section{Kesimpulan}

Berdasarkan hasil yang dicapai dalam penelitian ini maka dapat disimpulkan bahwa perancangan sistem informasi perpustakaan berbasis web dengan pemanfaatan barcode scanner di MI Nurul Huda Argopeni ini telah berhasil dibuat dan diimplementasikan, di mana terjadi peningkatan efisiensi dan efektivitas pada perpustakaan setelah mengimplementasikan sistem ini.

\section{Daftar Pustaka}

[1] Amin, M. (2016). Analisis Penjualan Komputer Pada Putra Jawa Computer Berbasis Web. 7(4), 250-261.

[2] Dedi Saputra, Setiaji, Riswandi Ishak. (2019). Perancangan Sistem Informasi Pengelolaan dan Pelayanan Perpustakaan Berbasis Web. Jurnal Mantik Penusa, 33-42.

[3] Esfimal Malau, Agus Salim, Budi Santoso, Rino Ramadan. (2018). Sistem Informasi Manajemen Perpustakaan Dengan Barcode di GKI Gunung Sahari Jakarta. Bina Insani Ict Journal, $41-50$.

[4] Fauzi, R. A. (2017). Sistem Informasi Akuntansi (Berbasis Akuntansi). Yogyakarta: Deepublish.

[5] Fitriyani, M. R. (2017). Sistem Informasi Pengelolaan Perpustakaan Berbasis Qrcode. Surakarta: Program Studi Informatika Fakultas Komunikasi dan Informatika Universitas Muhammadiyah Surakarta.

[6] Hayati Noor, Fakhri Aniekawati, Dwi Agungwibowo. (2020). Sistem Informasi Perpustakaan Berbasis Web Menggunakan Barcode pada SMP Negeri 11 Banjarmasin. Jurnal Technologia, 71.

[7] Hermanto, Ikhsan Firmansyah. (2020). Rancang Bangun Sistem Perpustakaan Berbasis Web Support Qr-Code. Jurnal Sistem Informasi Dan Telematika, 134.

[8] Ismail, I. (2021). Retrieved September 01, 2021, from www.accurate.id: https://accurate.id/marketingmanajemen/barcode-adalah/
Kuswara, H., \& Kusmana, D. (2017). Sistem Informasi Absensi Siswa Berbasis Web Dengan SMS Gateway Pada Sekolah Menengah Kejuruan Al-Munir Bekasi.
Indonesian Journal On Networking And Security, 6(2), , 17-22.

[10] Musa Hubeis Dkk. (2012). Komunikasi Profesional. Bogor. Bogor: IPB Press.

[11] Nadaek Berto, Abbas Parulian, Pristiwanto, Saidi Ramadan Siregar. (2016). Perancangan Aplikasi Pembelajaran Internet dengan Menggunakan Metode Computer Based Intruction. Journal Riset Komputer Vol.3 , 54.

[12] Nur, Rusdi.Dkk. (2018). Perancangan Mesin-Mesin Industri. Yogyakarta: Deepublish.

[13] Pirmayani, W., \& Susyatih, E. (2017, September 24). Sistem Informasi Anggaran Pendapatan dan Belanja Desa Berorientasi Objek. Khatulistiwa Informatika, V(1), 5863.

[14] Pratama, A. R. (2019, Januari 21). Belajar Unified Modeling Language (UML)Pengenalan. Retrieved Juni 5, 2021, From Codepolitan:

https://www.codepolitan.com/unifiedmodeling-language-uml

[15] Rerung, R. (2018). Pemrograman Web Dasar. Yogyakarta: Deeppublish.

[16] Rosa. (2013). Rekayasa Perangkat Lunak. Bandung: Informatika Bandung.

[17] Susilowati, Y. (2019). Module E-Commerce -Teaching Factory For Students. Blitar: Mutiara Publisher.

[18] Yolanda. (2018). Retrieved September 01, 2021, from www.olsera.com: https://www.olsera.com/id/blog/apa-itubarcode-scanner-mengenal-definisi-danjenis-jenis-barcode-scanner/41 